\title{
Effects of Cadmium Stress on Photosynthesis of Cyphomandra betacea Seedlings
}

\author{
Mei Qing ${ }^{1, a}$, Lijin Lin ${ }^{2, b}$ and Ming'an Liao ${ }^{1, c *}$ \\ ${ }^{1}$ College of Horticulture, Sichuan Agricultural University, Chengdu, Sichuan, China \\ ${ }^{2}$ Institute of Pomology and Olericulture, Sichuan Agricultural University, Chengdu, Sichuan, China \\ a1115435013@qq.com, bllj800924@qq.com, Iman@sicau.edu.cn \\ ${ }^{*}$ Corresponding author. Mei Qing and Lijin Lin contributed equally to this work.
}

\section{Keywords: Cyphomandra betacea; Photosynthetic; Cadmium stress}

Abstract: A pot experiment was conducted to study the effects of cadmium (Cd) stress on photosynthetic characteristics of Cyphomandra betace seedlings. The annual C. betacea seedlings were treated with $\mathrm{Cd}$ of different concentration gradients $(0-20 \mathrm{mg} / \mathrm{kg})$. The results showed that with the increase of soil $\mathrm{Cd}$ concentration, the chlorophyll $a$, chlorophyll $b$, total chlorophyll and carotenoid content of $C$. betacea decreased, the net photosynthetic rate, stomatal conductance, $\mathrm{CO}_{2}$ concentration of intercellular, transpiration rate and light use efficiency decreased, the vapor pressure deficit of leaf and water use efficiency increased, compared with the control. Therefore, $\mathrm{Cd}$ stess could effect the photosynthesis of $C$. betacea seedlings significiently, and had a bad influnence on their growth.

\section{Introduction}

Cyphomandra betacea is a kind of fruit tree with commercial development value [1], it belongs to the Solanaceae family, native to Peru, South America and is now mostly cultivated in southwest China [2]. C. betacea can be both ornamental and edible, and is thought to has the potential to develop as an effective drug for cancer [3]. Previous studies have shown that cadmium (Cd) might strongly inhibit plant growth by reducing chlorophyll content, damaging plant cell structure, destroying physiological metabolic processes such as photosynthesis., and even led to plant death $[4,5]$. For Photosynthesis, Cd stress could lead to the increase of relative electrical conductivity and the injury of Medicago sativa leaves [6],could also reduce the photosynthetic capacity and fluorescent parameters of Nicotiana tabacum [7], and could effect the electron transfer in the process of photosynthesis, and might have a hormesis in Lonicera japonica Thunb[8]. But there are significant differences in the sensitivity and tolerance of different crops to $\mathrm{Cd}$ stress[9].Therefore, a pot experiment was conduct to study the photosynthetic Characteristics of $C$. betacea seedlings in soil with $\mathrm{Cd}$ of different concentration gradients $(0-20 \mathrm{mg} / \mathrm{kg})$. The objectives of this study were to provide guidance for the cultivation, application and safe production of $C$. betacea.

\section{Materials and Methods}

Materials. The seeds of $C$. betacea were collected from a perennial $C$. betacea of Chengdu Academy of Agriculture and Forestry $\left(30^{\circ} 42^{\prime} \mathrm{N}, 103^{\circ} 51^{\prime} \mathrm{E}\right)$ in August, 2016, air-dried and stored at $4{ }^{\circ} \mathrm{C}$ respectively.

Experimental Design. The experiment was conducted at Chengdu Campus of Sichuan Agricultural University $\left(30^{\circ} 42^{\prime} \mathrm{N}, 103^{\circ} 51^{\prime} \mathrm{E}\right)$ from May to August 2017. The soil samples were air-dried and passed through a 5-mm mesh in May 2017, and then $3.0 \mathrm{~kg}$ of soil was weighed into each polyethylene pot $(15 \mathrm{~cm}$ tall, $18 \mathrm{~cm}$ diameter $) . \mathrm{Cd}$ was added to make a final soil $\mathrm{Cd}$ concentrations of $0,1,5,10,15,20 \mathrm{mg} / \mathrm{kg}$ with a saturated heavy metal solution in the form of $\mathrm{CdCl}_{2} \cdot 2.5 \mathrm{H}_{2} \mathrm{O}$. The soils were mixed aperiodically during the next 4 weeks, and the soil moisture was kept at $80 \%$. The seeds of $C$. betacea were sown in the farmland of the Chengdu Campus in June 2017. Two weeks later, three seedlings of each treatment were transplanted into each pot, and each treatment was repeated five times with a $10-\mathrm{cm}$ spacing between pots. In order to reduce the 
marginal effect, the position of the pots was completely randomly arranged and exchanged during the whole growth process. When $C$. betacea seedlings grow two month (August 2017) under $\mathrm{Cd}$ stress, the upper mature leaves of $C$. betacea were collected to determine the photosynthetic pigment (chlorophyll $a$, chlorophyll $b$, total chlorophyll and carotenoid) content [10]. The photosynthesis of each plant was determined by using LI-6400 portable photosynthesis meter (LI-COR Inc, USA). The photosynthetic parameters of the photosynthesis meter were manual controled, with $\mathrm{CO}_{2}$ concentration $400 \mu \mathrm{mol} / \mathrm{mol}$, temperature $25{ }^{\circ} \mathrm{C}$, light intensity 1000 $\left.\mu \mathrm{mol} / \mathrm{m}^{2} / \mathrm{s}^{1}\right)$. The determination of photosynthetic parameters were net photosynthetic rate $(\mathrm{Pn})$, transpiration rate $(\mathrm{Tr})$, vapor pressure $(\mathrm{VpdL})$, stomatal conductance $(\mathrm{Gs})$ and $\mathrm{CO}_{2}$ concentration of intercellular $(\mathrm{Ci})$, and each treatment was repeated three times. Water use efficiency $($ WUE$)=$ net photosynthetic rate $(\mathrm{Pn}) /$ transpiration rate $(\mathrm{Tr})$, Light use efficiency (LUE) = net photosynthetic rate $(\mathrm{Pn}) /$ light intensity [11].

Statistical Analyses. Statistical analyses were conducted using SPSS 17.0 statistical software (IBM, Chicago, IL, USA). Data were analyzed by one-way analysis of variance with least significant difference (LSD) at the $\mathrm{p}=0.05$ confidence level.

\section{Results and Discussion}

Photosynthetic Pigment Content in $C$. betacea seedlings. Cd decreased the content of chlorophyll $a$, chlorophyll $b$, total chlorophyll and carotenoid in $C$. betacea seedlings (Table 1). The content of chlorophyll $a$, chlorophyll $b$, total chlorophyll and carotenoid were similar to the contorl when the soil Cd concentration was less than $5 \mathrm{mg} / \mathrm{kg}$. But with the increase of soil Cd concentration, they decreased evidently. Under soil Cd concentration of $1,5,10,15$ and $20 \mathrm{mg} / \mathrm{kg}$, the chlorophyll $a$ content decreased by $-2.84 \%(P>0.05), 7.75 \%(P>0.05), 16.03 \%(P<0.05), 21.22 \%(P<0.05)$ and $21.29 \%(P<0.05)$ respectively, the chlorophyll $b$ content decreased by $-6.02 \%(P>0.05)$, 4.87\% $(P>0.05), 14.39 \%(P<0.05), 23.19 \%(P<0.05)$ and $16.08 \%(P<0.05)$ respectively, the total chlorophyll content decreased by $-2.910(P>0.05), 7.01 \%(P>0.05), 15.59 \%(P<0.05)$, $21.73 \%(P<0.05)$ and $19.95 \%(P<0.05)$ respectively, the carotenoid content decreased by -0.39 $(P>0.05), 6.60 \%(P>0.05), 9.21 \%(P<0.05), 20.66 \%(P<0.05)$ and $15.91 \%(P<0.05)$ respectively, compared with the control. Cd stress decreased the chlorophyll $a / b$ of $C$. betacea seedlings.

Table 1 Photosynthetic pigment content in C. betacea seedlings

\begin{tabular}{|c|l|l|l|l|l|}
\hline $\begin{array}{c}\text { Cd } \\
\text { concentration } \\
(\mathrm{mg} / \mathrm{kg})\end{array}$ & $\begin{array}{c}\text { Chlorophyll } a \\
(\mathrm{mg} / \mathrm{g})\end{array}$ & $\begin{array}{c}\text { Chlorophyll } b \\
(\mathrm{mg} / \mathrm{g})\end{array}$ & $\begin{array}{c}\text { Total } \\
\text { chlorophyll } \\
(\mathrm{mg} / \mathrm{g})\end{array}$ & $\begin{array}{c}\text { Chlorophyll } \\
a / b\end{array}$ & $\begin{array}{c}\text { Carotenoid } \\
(\mathrm{mg} / \mathrm{g})\end{array}$ \\
\hline 0 & $5.279 \pm 0.098 \mathrm{ab}$ & $1.828 \pm 0.047 \mathrm{ab}$ & $7.107 \pm 0.145 \mathrm{ab}$ & $2.887 \pm 0.021 \mathrm{ab}$ & $1.031 \pm 0.020 \mathrm{a}$ \\
\hline 1 & $5.376 \pm 0.023 \mathrm{a}$ & $1.938 \pm 0.010 \mathrm{a}$ & $7.314 \pm 0.013 \mathrm{a}$ & $2.775 \pm 0.026 \mathrm{~cd}$ & $1.035 \pm 0.010 \mathrm{a}$ \\
\hline 5 & $4.870 \pm 0.237 \mathrm{bc}$ & $1.739 \pm 0.081 \mathrm{~b}$ & $6.609 \pm 0.318 \mathrm{bc}$ & $2.801 \pm 0.006 \mathrm{c}$ & $0.963 \pm 0.065 \mathrm{ab}$ \\
\hline 10 & $4.433 \pm 0.336 \mathrm{~cd}$ & $1.565 \pm 0.106 \mathrm{c}$ & $5.999 \pm 0.442 \mathrm{~cd}$ & $2.831 \pm 0.024 \mathrm{bc}$ & $0.936 \pm 0.029 \mathrm{bc}$ \\
\hline 15 & $4.159 \pm 0.123 \mathrm{~d}$ & $1.404 \pm 0.056 \mathrm{~d}$ & $5.563 \pm 0.179 \mathrm{~d}$ & $2.964 \pm 0.031 \mathrm{a}$ & $0.818 \pm 0.023 \mathrm{~d}$ \\
\hline 20 & $4.155 \pm 0.225 \mathrm{~d}$ & $1.534 \pm 0.044 \mathrm{~cd}$ & $5.689 \pm 0.269 \mathrm{~d}$ & $2.708 \pm 0.069 \mathrm{~d}$ & $0.867 \pm 0.022 \mathrm{~cd}$ \\
\hline
\end{tabular}

Different lowercase letters indicate significant differences based on one-way analysis of variance in SPSS 17.0 followed by the least significant difference test $(P<0.05) .0=\mathrm{Cd}$ free, $1=1 \mathrm{mg} / \mathrm{kg}$ soil Cd concentration, $5=5 \mathrm{mg} / \mathrm{kg}$ soil Cd concentration, $10=10 \mathrm{mg} / \mathrm{kg}$ soil Cd concentration, $15=15$ $\mathrm{mg} / \mathrm{kg}$ soil $\mathrm{Cd}$ concentration, $20=20 \mathrm{mg} / \mathrm{kg}$ soil Cd concentration. The same as below.

Photosynthetic Characteristics of $\boldsymbol{C}$. betacea seedlings. Cd stress had a significant effect on the photosynthesis of $C$. betacea seedlings (Table 2). Compared with the respective control, Cd stress decreased the Pn of $C$. betacea seedlings, and increased the Vpdl of that. With the increase of soil Cd concentration, the Gs, $\mathrm{Ci}$ and $\mathrm{Tr}$ increased when the of Cd concentration was less than $1 \mathrm{mg} / \mathrm{kg}$, and decreased when the Cd concentration was more than $1 \mathrm{mg} / \mathrm{kg}$. Under soil Cd concentration of 1 
$\mathrm{mg} / \mathrm{kg}$, C. betacea seedlings decreased Pn and VpdL by $5.72 \%(P<0.05)$ and $23.96 \%(P<0.05)$, respectively, increased $\mathrm{Gs}, \mathrm{Ci}$ and $\mathrm{Tr}$ by $65.99 \%(P<0.05), 27.99 \%(P<0.05)$ and $21.89 \%(P<$ 0.05). Under soil Cd concentration of $5,10,15$ and $20 \mathrm{mg} / \mathrm{kg}$, the Pn decreased by $33.78 \%(P<$ $0.05), 41.22 \%(P<0.05), 38.16 \%(P<0.05)$ and $49.20 \%(P<0.05)$ respectively, the Gs dereeased by $54.89 \%(P<0.05), 50.48 \%(P<0.05), 36.28 \%(P<0.05)$ and $47.97 \%(P<0.05)$ respectively, the $\mathrm{Ci}$ hardly changed respectively, the Tr decreased by $58.81 \%(P<0.05), 48.90 \%(P<0.05)$, $53.29 \%(P<0.05)$ and $47.65 \%(P<0.05)$ respectively. the VpdL increased by $0.51 \%(P>0.05)$, 7.51\% $(P<0.05), 5.63 \%(P<0.05)$ and $12.86 \%(P<0.05)$ respectively. For WUE, Fig. 1 shows that $\mathrm{Cd}$ stress treatment increased the water use efficiency of $C$. Betacea. Compared with the control, the WUE was $29.87 \%(P<0.05)$ lower under soil Cd concentration of $1 \mathrm{mg} / \mathrm{kg}$, and increased by $60.59 \%(P<0.05)$ and $32.84 \%(P<0.05)$ under soil Cd concentration of 5 and 15 $\mathrm{mg} / \mathrm{kg}$ respectively. The same as the Pn, Cd stress decreased the LUE of C.betacea seedlings (Fig. 2). The light use efficiency of $C$.betacea seedlings decreased by $5.33 \%(P<0.05), 32 \%(P<0.05)$, 41.33\% $(P<0.05), 37.33 \%(P<0.05)$, and 49.33\% $(P<0.05)$ respectively under soil $\mathrm{Cd}$ concentration of $1,5,10,15$ and $20 \mathrm{mg} / \mathrm{kg}$.

Table 2 Photosynthetic characteristics of $C$. betacea seedlings

\begin{tabular}{|c|c|c|c|c|c|}
\hline $\begin{array}{c}\mathrm{Cd} \\
\begin{array}{c}\text { concentration } \\
(\mathrm{mg} / \mathrm{kg})\end{array}\end{array}$ & $\begin{array}{c}\mathrm{Pn} \\
(\mu \mathrm{mol} \\
\left.\mathrm{CO}_{2} / \mathrm{m}^{2} / \mathrm{s}\right)\end{array}$ & $\begin{array}{c}\mathrm{Gs} \\
\left(\mathrm{mol} \mathrm{H} / 2 \mathrm{O} / \mathrm{m}^{2} / \mathrm{s}\right)\end{array}$ & $\begin{array}{c}\mathrm{Ci} \\
(\mu \mathrm{mol} \\
\left.\mathrm{CO}_{2} / \mathrm{mol}\right)\end{array}$ & $\begin{array}{c}\mathrm{Tr} \\
(\mathrm{mmol} \\
\left.\mathrm{H}_{2} \mathrm{O} / \mathrm{m}^{2} / \mathrm{s}\right)\end{array}$ & VpdL $(\mathrm{kPa})$ \\
\hline 0 & $7.52 \pm 0.41 \mathrm{a}$ & $0.0838 \pm 0.0003 \mathrm{~b}$ & $241.59 \pm 20.00 \mathrm{~b}$ & $1.595 \pm 0.006 \mathrm{~b}$ & $1.757 \pm 0.129 \mathrm{c}$ \\
\hline 1 & $7.09 \pm 0.03 \mathrm{~b}$ & $0.1391 \pm 0.0008 \mathrm{a}$ & $309.20 \pm 9.89 \mathrm{a}$ & $2.152 \pm 0.159 \mathrm{a}$ & $1.336 \pm 0.065 \mathrm{~d}$ \\
\hline 5 & $4.98 \pm 0.01 \mathrm{c}$ & $0.0378 \pm 0.0009 \mathrm{~d}$ & $174.12 \pm 6.21 \mathrm{~d}$ & $0.657 \pm 0.014 \mathrm{~d}$ & $1.766 \pm 0.003 \mathrm{c}$ \\
\hline 10 & $4.42 \pm 0.06 \mathrm{~d}$ & $0.0415 \pm 0.0005 \mathrm{~d}$ & $204.30 \pm 15.04 \mathrm{c}$ & $0.815 \pm 0.008 \mathrm{c}$ & $1.889 \pm 0.012 \mathrm{~b}$ \\
\hline 15 & $4.65 \pm 0.05 \mathrm{~d}$ & $0.0534 \pm 0.0026 \mathrm{c}$ & $243.46 \pm 22.24 \mathrm{~b}$ & $0.745 \pm 0.058 \mathrm{~cd}$ & $1.856 \pm 0.107 \mathrm{~b}$ \\
\hline 20 & $3.82 \pm 0.06 \mathrm{e}$ & $0.0436 \pm 0.0020 \mathrm{~cd}$ & $245.67 \pm 19.26 \mathrm{~b}$ & $0.835 \pm 0.075 \mathrm{c}$ & $1.983 \pm 0.015 \mathrm{a}$ \\
\hline
\end{tabular}
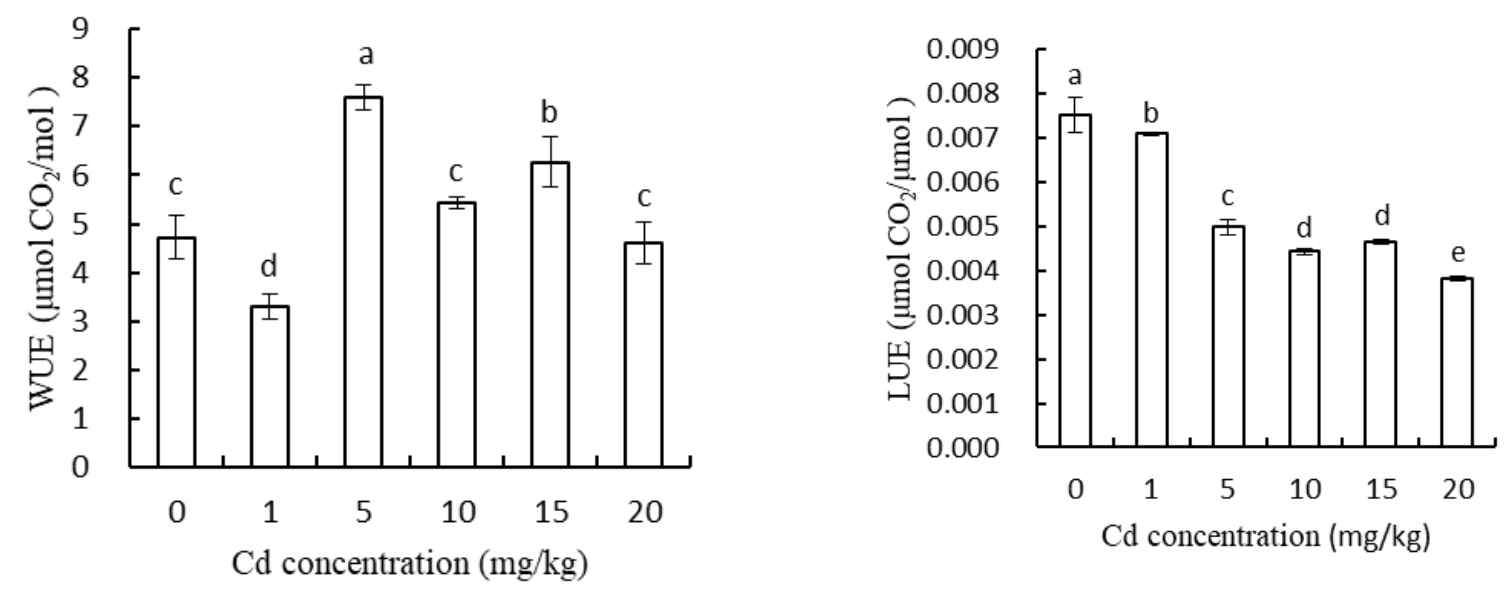

Fig. 1 WUE of $C$. betacea seedlings. Values are Fig. 2 LUE of $C$. betacea seedlings. Values are means of three replicate pots. Different means of three replicate pots. Different lowercase letters indicate significant differences lowercase letters indicate significant differences based on one-way analysis of variance in SPSS based on one-way analysis of variance in SPSS 17.0 followed by the least significant difference 17.0 followed by the least significant difference test $(P<0.05) .0=\mathrm{Cd}$ free, $1=1 \mathrm{mg} / \mathrm{kg}$ soil $\mathrm{Cd}$ test $(P<0.05) .0=\mathrm{Cd}$ free, $1=1 \mathrm{mg} / \mathrm{kg}$ soil concentration, $5=5 \mathrm{mg} / \mathrm{kg}$ soil $\mathrm{Cd} \mathrm{Cd}$ concentration, $5=5 \mathrm{mg} / \mathrm{kg}$ soil $\mathrm{Cd}$ concentration, $10=10 \mathrm{mg} / \mathrm{kg}$ soil $\mathrm{Cd}$ concentration, $10=10 \mathrm{mg} / \mathrm{kg}$ soil $\mathrm{Cd}$ concentration, $15=15 \mathrm{mg} / \mathrm{kg}$ soil $\mathrm{Cd}$ concentration, $15=15 \mathrm{mg} / \mathrm{kg}$ soil $\mathrm{Cd}$ concentration, $20=20 \mathrm{mg} / \mathrm{kg}$ soil $\mathrm{Cd}$ concentration, $20=20 \mathrm{mg} / \mathrm{kg}$ soil $\mathrm{Cd}$ concentration. concentration. 


\section{Conclusions}

Under Cd stess, the chlorophyll $a$, chlorophyll $b$, total chlorophyll and carotenoid content in $C$. betacea decreased, the Pn, Gs, Ci, Tr and LUE decreased, the Vpdl and WUE increased compared with the control. The results showed that with the increase of soil $\mathrm{Cd}$ concentration, the photosynthesis of $C$. betacea seedlings increased when the concentration of $\mathrm{Cd}$ was less than 1 $\mathrm{mg} / \mathrm{kg}$ and decreased when the concentration was more that. Therefore, $\mathrm{Cd}$ stess could effect the photosynthesis of $C$. betacea seedlings by decreasing the photosynthetic pigment content, the Pn, Gs, $\mathrm{Ci}$, Tr and LUE.

\section{Acknowledgements}

This work was financially supported by the Project of Sichuan Provincial Education Department (17ZB0342).

\section{References}

[1] J.A.M.V.D. Mey and G.A.M.V. Hasselt: Genetica Vol. 40(1969), p. 413.

[2] S. Zhi, Y.X. Wu, Y.J. Wang, H. Hui and Z.X. Huang: Hubei agricultural science Vol. 53(2014), p. 5880.

[3] M.A. Mutalib, F. Ali, F. Othman, R. Ramasamy and A. Rahmat: SpringerPlus Vol. 5(2016), p. 2105.

[4] L. Ran and H.H. Li: Journal of Chongqing University of Arts and Sciences Vol. 30(2011), p. 69.

[5] J.R. Guo: Shaanxi Journal of Agricultural science Vol. 11(2017), p. 13.

[6] N.X. Sun and G.L. Song: Pratacultural Science Vol. 32(2015), p. 581.

[7] K. Wu, Z.H. Wu, F.J. Tai, Y. Han, B. E. Xie and Z.L. Yuan: Acta Ecologica Sinica Vol. 31(2011), p. 4517.

[8] Z.L. Liu, W. Chen, X.Y. He, S. Yu, X.Q. Huang, W.H. Ding, Y. Zhang and D.Y. Su: Enviroment Chemistry Vol. 37(2018), p. 223.

[9] J.Shi, R.P. Hu, L.L. Lin, T.Y. Huang, X.D. Zhu and C. Chun: Journal of Gansu Agricultural University Vol. 51(2016), p. 120.

[10]Z.B. Hao, J. Cang and Z. Xu: Plant Physiology Experiment (Harbin Institute of Technology Press, Harbin, China 2004).

[11]X.J. Jiang, H. Wang, W. Peng, Y.X. Yang, X.M. Zhu and L.J. Lin: Shanxi Journal of Agricultural Sciences Vol. 54 (2008), p. 56. 